$\begin{array}{cc}\text { ACADEMIA ROMÂNĂ } & \text { Rev. Roum. Chim., } \\ \text { Revue Roumaine de Chimie } & \text { 2020, 65(4), 353-360 } \\ \text { http://web.icf.ro/rrch/ } & \text { DOI: 10.33224/rrch.2020.65.4.04 }\end{array}$

\title{
CORROSION INHIBITION OF STEEL BY PRICKLY PEAR: EXTRACTION, CHARACTERIZATION AND ELECTROCHEMICAL STUDIES
}

\author{
Imen ABIDLI, ${ }^{\mathrm{a}, *}$ Nebil SOUISSI ${ }^{\mathrm{a}}$ and X. Ramón NÓVOA ${ }^{\mathrm{b}}$ \\ ${ }^{\text {a } U n i v e r s i t y ~ o f ~ T u n i s ~ E l ~ M a n a r, ~ P r e p a r a t o r y ~ I n s t i t u t e ~ f o r ~ E n g i n e e r i n g ~ S t u d i e s, ~ B P ~} 244$ El Manar II, 2092 El Manar, Tunis, Tunisia \\ ${ }^{\mathrm{b}}$ University of Vigo, School of Industrial Engineering, E-36310-Vigo, Spain
}

Received October 5, 2019

Aqueous and Methanolic extracts of Prickly Pear was tested as a corrosion inhibitor for mild steel using electrochemical impedance spectroscopy (EIS) in two different media. Impedance measurements showed that there are two phenomena in the inhibition process. The obtained results show that this plant extract could serve as an effective inhibitor for corrosion of steel in $\mathrm{NaOH}$ solutions with different $\mathrm{NaCl}$ content. The aqueous extract obtained gives inhibition around $96.9 \%$ in $0.1 \mathrm{M}$ $\mathrm{NaOH}$ solution and the methanolic extract provided about $88.3 \%$ inhibition efficiency in $0.1 \mathrm{M} \mathrm{NaOH}+0.5 \mathrm{M} \mathrm{NaCl}$ solution. The EIS experimental data show frequency dispersion and therefore a modeling element with frequency dispersion behavior, a constant phase (CPE) has been used.

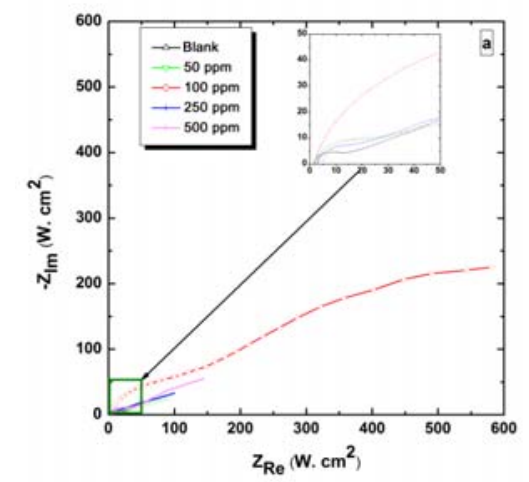

Pear is found to contain carbohydrates, protein, lipids, amino acids, vitamins, minerals, polyphenols, and betalain pigments. ${ }^{15,16}$ Most of those compounds are potential corrosion inhibitors, specially amino acids $^{2}$ and polyphenols. ${ }^{3,4}$

This study aims at gaining some insight into the corrosion inhibition of steel in three different alkaline media by aqueous and methanol extracts from Prickly Pear plant.

\section{RESULTS AND DISCUSSION}

\section{Open circuit potential}

The evolution of the open circuit potential $\left(\mathrm{E}_{\mathrm{OCP}}\right)$ with time for mild steel in different medias without and with Prickly Pear extracts was measured. Before each electrochemical impedance 
spectroscopy (EIS) experiments, the electrode was allowed to corrode freely and its open circuit potential $\left(\mathrm{E}_{\mathrm{OCP}}\right)$ was recorded as a function of time up to 180 seconds. After this time a steady state OCP, corresponding to the corrosion potential of the working electrode, was obtained. The above procedures were repeated on $100 \mathrm{ppm}$ of concentration of Prickly Pear methanolic extract and $100 \mathrm{ppm}$ of concentration of Prickly Pear aqueous extract in $0.1 \mathrm{M} \mathrm{NaOH}+0.5 \mathrm{M} \mathrm{NaCl}$ and $0.1 \mathrm{M}$ $\mathrm{NaOH}$ respectively. The evolution of the open circuit potential $\left(\mathrm{E}_{\mathrm{OCP}}\right)$ with time for mild steel in different medias revealed that the plots showed clear modifications in the $\mathrm{E}_{\mathrm{OCP}}$ - time behavior due to the presence of Prickly Pear extracts.

Without inhibitor, the electrode of mild steel had an $\mathrm{E}_{\mathrm{OCP}}-0.55 \mathrm{Vvs}$.SCE and $-0.37 \mathrm{Vvs.SCE}$ at $\mathrm{t}=0 \mathrm{~min}$ and at $\mathrm{t}=240 \mathrm{~min}$, respectively. Therefore, the oxide film is formed over time, the one that covers the surface and performs the anodic displacement of the potential. When inhibitor was present in the electrolyte solution at $\mathrm{t}=160 \mathrm{~min}$, a positive shift in $\mathrm{E}_{\mathrm{OCP} W a s}$ changed from -0.36 Vvs.SCE in the uninhibited solution to -0.3 Vvs.SCE. At $t=240 \mathrm{~min}$, the electrode of mild steel had an $\mathrm{E}_{\mathrm{OCP}}-0.28 \mathrm{Vvs}$.SCE. The positive shift in $E_{O C P}$ indicated that the molecules inhibited theanodic corrosion of mild steel.

Without inhibitor, the electrode of mild steel had an $\mathrm{E}_{\mathrm{OCP}}-0.39$ Vvs.SCE and -0.5 Vvs.SCE at $\mathrm{t}=0 \mathrm{~min}$ and at $\mathrm{t}=140 \mathrm{~min}$, respectively. This cathodic displacement is due to the corrosion of the surface incuring by the $\mathrm{Cl}^{-}$ions attak. From $\mathrm{t}=160 \mathrm{~min}$ to $\mathrm{t}=240 \mathrm{~min}$, the electrode of mild steel had an $\mathrm{E}_{\mathrm{OCP}}-0.45 \mathrm{Vvs} . \mathrm{SCE}$ and -0.48 Vvs.SCE. An anodic displacement was observed and decrease towards the cathodic values. In the employed chloride environment, a magnetite-rich passive layer develops at the metallic surface ${ }^{22,23}$ that tends to dissolve locally in the presence of chlorides ${ }^{24}$. When inhibitor was present in the electrolyte solution at $\mathrm{t}=160 \mathrm{~min}$, a positive shift in $\mathrm{E}_{\mathrm{OCP}}$ was changed from -0.45 Vvs.SCE in the uninhibited solution to -0.35 Vvs.SCE. At $t=240$ min, the electrode of mild steel had an $\mathrm{E}_{\mathrm{OCP}}-0.28 \mathrm{Vvs.SCE}$. The positive shift in $\mathrm{E}_{\mathrm{OCP}}$ indicated that the presence of inhibitor is expected to affect the building up of the passive layer, and passivity breakdown.

\section{Electrochemical impedance spectroscopy}

The impedance method has been used to get the information about kinetics of the electrode processes and, simultaneously, about the surface properties of the investigated systems.

The method is widely used for investigation of the corrosion inhibition processes. ${ }^{25,26}$

Fig. 2 shows the Nyquist and Bode-phase plots for mild steel in $0.1 \mathrm{M} \mathrm{NaOH}+0.5 \mathrm{M} \mathrm{NaCl}$ and in $0.1 \mathrm{M} \mathrm{NaOH}$ solutions in absence and presence of various concentrations of Prickly Pear methanolic and aqueous extracts, respectively at $25^{\circ}$. The impedance spectra obtained for the corrosion of studied mild steel in $0.1 \mathrm{M} \mathrm{NaOH}+0.5 \mathrm{M} \mathrm{NaCl}$ and in $0.1 \mathrm{M} \mathrm{NaOH}$ solutions with and without inhibitor consist of two capacitive loops (two well-defined time-constants in the phase format; Fig. $2 \mathrm{~b}$ and Fig. 2d). The high-frequency (HF) loop, the smaller one, can be attributed to the film formation at the steel surface while the low-frequency (LF) loop, the larger one, can be attributed to the charge transfer reaction. Fig. 2a and Fig. 2c exhibit two single depressed semicircles. The diameter of the semicircle at high frequency reached the maximum at $100 \mathrm{ppm}$ of Prickly Pear methanolic extract. The high frequency time constant corresponds to the charge transfer resistance in parallel to the double layer capacitance. The low frequency tail can be either attributed to oxygen diffusion or redox transformations $\left(\mathrm{Fe}^{3+} / \mathrm{Fe}^{2+}\right)$ at the electrode surface, or both phenomena with some degree of overlapping. According to the shape of the experimental EIS spectra, the low frequency tile approaches Warburg-type diffusion only for the blank solution and that containing $50 \mathrm{ppm}$ inhibitor (all spectra fitted by the same model). For higher inhibitor concentrations, the charge transfer resistance increases (corrosion rate decreases) so that oxygen transport no longer controls the reaction rate and the low frequency time constant can be associated to redox transformations exclusively.

Excellent fit with the equivalent circuit model $R_{e}\left(C_{d l} R_{c t}\right)$ was obtained for all experimental data, depicted in Fig. 3a. In this equivalent circuit, Re is the electrolyte resistance, $R_{c t}$ is the charge transfer resistance and CPE is substituted for the capacitive element to give a more accurate fit, as most capacitive loops are depressed semicircles rather than regular semicircles. As an example, the Nyquist plots of experimental data (in the presence of 100 ppm Prickly Pear methanolic extract) and simulated are presented in Fig. 3b. The deviation of semicircles from perfect circular shape is often referred to the frequency dispersion of interfacial impedance $e^{27,28}$. This behavior is usually attributed to the inhomogeneity of the metal surface arising from surface roughness or interfacial phenomena ${ }^{29,30}$ which is typical for solid metal electrodes. ${ }^{31}$ 

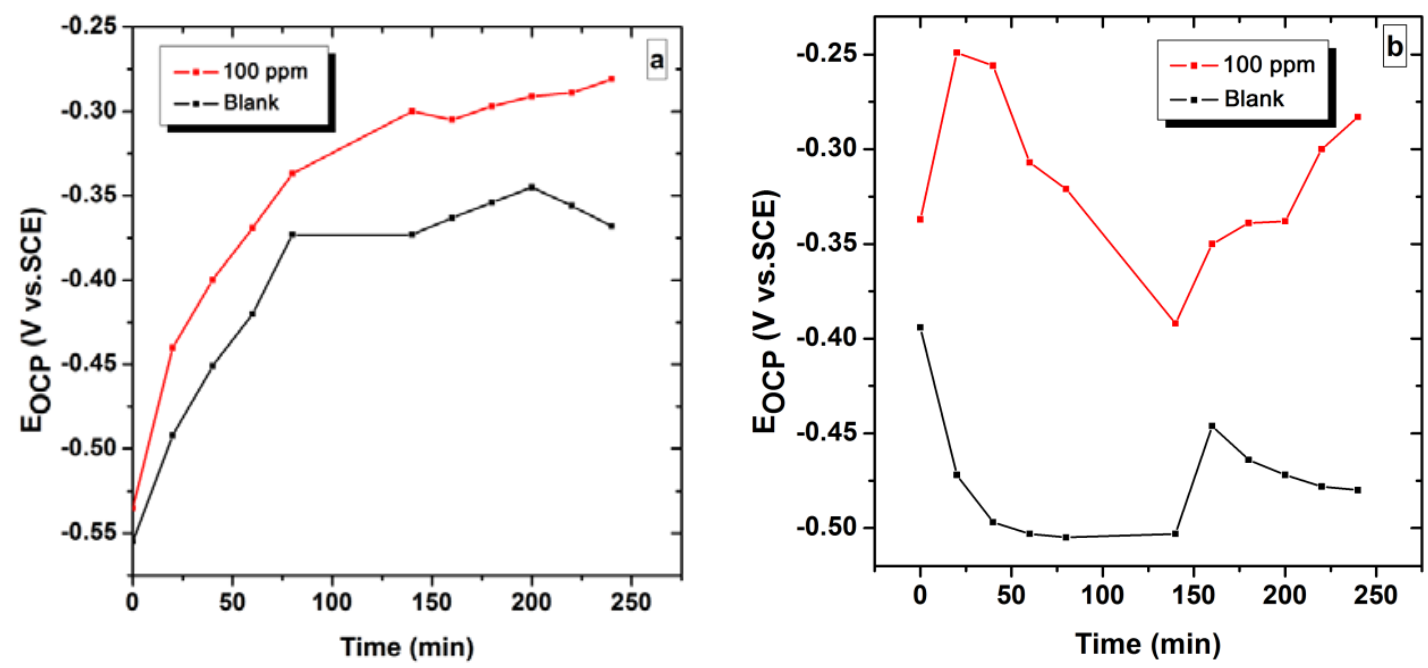

Fig. 1 - Open-circuit potential - time variation of carbon steel in: a) $0.1 \mathrm{M} \mathrm{NaOH}$ solution without and with Prickly Pear aqueous extract b) $0.1 \mathrm{M} \mathrm{NaOH}+0.5 \mathrm{M} \mathrm{NaCl}$ solution without and with Prickly Pear methanolic extract.
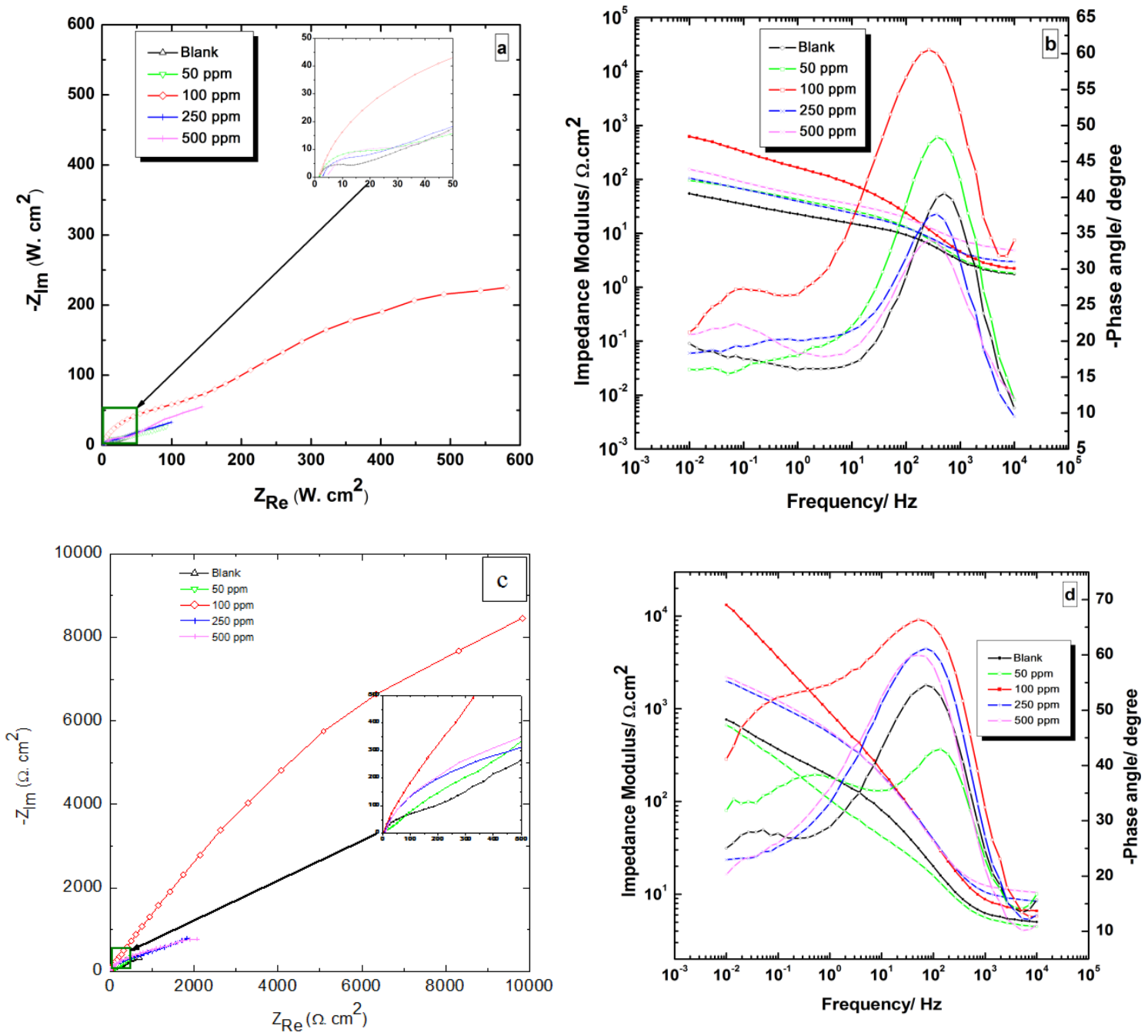

Fig. 2 - Electrochemical impedance spectra of carbon steel a) Nyquist plot in $0.1 \mathrm{M} \mathrm{NaOH}+0.5 \mathrm{M} \mathrm{NaCl}$ solution without and with Prickly Pear methanolic extract b) Bode-phase angle plotsin $0.1 \mathrm{M} \mathrm{NaOH}+0.5 \mathrm{M} \mathrm{NaCl}$ solution without and with Prickly Pear methanolic extract c) Nyquist plot in $0.1 \mathrm{M} \mathrm{NaOH}$ solution without and with Prickly Pear aqueous extract d) Bode phase angle plot in $0.1 \mathrm{M} \mathrm{NaOH}$ solution without and with Prickly Pear aqueous extract. 


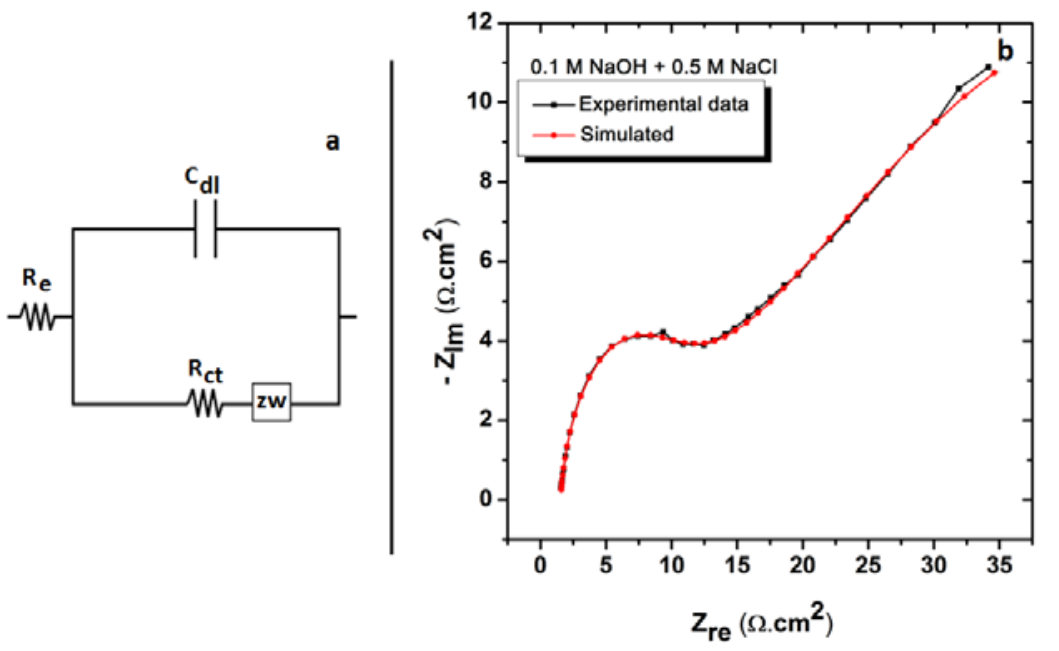

Fig. 3 - a) Equivalent circuits of electrochemical impedance spectra integrating the effect of diffusion of a Warburg impedance without and with inhibitor b) Experimental and computer fitted results of Nyquist plot for mild steel in $0.1 \mathrm{M} \mathrm{NaOH}+0.5 \mathrm{M} \mathrm{NaCl}$ solution containing 100 ppm of Prickly Pear methanolic extract.

In this behavior of solid electrodes, the parallel network: charge transfer resistance-double layer capacitance is established where an inhibitor is present. For the description of a frequency independent phase shift between an applied ac potential and its current response, a constant phase element (CPE) is used which is defined in impedance representation as in Eq. (1). ${ }^{31}$

$$
Z_{\mathrm{CPE}}=\frac{1}{Q(j \omega)^{\alpha}}
$$

were $\mathrm{Q}$ is the magnitude of $\mathrm{CPE}, \alpha$ is the CPE exponent; $\omega$ is the angular frequency in $\operatorname{rad~s}^{-1}(\omega=$ $2 \pi f$ when $f$ is the frequency in $\mathrm{Hz}) ; \mathrm{j}=(-1)^{1 / 2}$ is an imaginary number, and $\mathrm{Z}_{\mathrm{CPE}}$, impedance of $\mathrm{CPE}$. The CPE, which is considered as a surface irregularity of the electrode, causes a greater depression in Nyquist semicircle diagram, where the metal-solution interface acts as a capacitor with irregular surface. If the electrode surface is homogeneous and plane, the exponential value $(\alpha)$ becomes equal to 1 and the metal-solution interface acts as a capacitor with regular surface. ${ }^{32}$ $\mathrm{C}_{\mathrm{dl}}$ values derived from CPE parameters according to Eq. (2) can be calculated: ${ }^{33}$

$$
\mathrm{C}_{\mathrm{dl}}=\mathrm{Q}_{\mathrm{dl}}\left(2 \pi f_{\max }\right)^{\alpha-1}
$$

where $f_{\max }$ represents the frequency at which imaginary value reaches a maximum on the Nyquist plot.

Various parameters such as the charge transfer resistance $\mathrm{R}_{\mathrm{tc}}$, double layer capacitance $\mathrm{C}_{\mathrm{dl}}$ and percentage inhibition efficiency were calculated from equivalent circuit model and listed in Table 1. The polarization resistance $(\mathrm{Rp})$ was calculated by:

$$
\mathrm{R}_{\mathrm{p}}=\mathrm{R}_{\mathrm{e}}+\mathrm{R}_{\mathrm{ct}}
$$

The values of IE \% are calculated using the following equation: ${ }^{34}$

$$
\operatorname{IE}(\%)=\frac{\operatorname{Rct}(\text { inh })-R c t}{\operatorname{Rct}(\text { inh })} * 100
$$

where $\mathrm{R}_{\mathrm{ct}}$ and $\mathrm{R}_{\mathrm{ct}(\mathrm{inh})}$ are charge transfer resistances in the absence and the presence of inhibitor. Inspection of data in Table 1 shows clearly that $R_{c t}$ and $\mathrm{C}_{\mathrm{dl}}$ values have opposite trend at the whole concentration range $\left(\mathrm{R}_{\mathrm{ct}}\right.$ increases and $\mathrm{C}_{\mathrm{dl}}$ decreases with inhibitor concentration). The double-layer capacitance reduced by increasing the concentration is in agreement with partial coverage of the surface by an insulating layer of low dielectric constant, ${ }^{5}$ as that provided by the inhibitor. This situation according to the Helmotz model was the result of an increase in the thickness of the electrical double layer or/an assigned to a decrease in local dielectric constant. ${ }^{35}$ The phase angle at high frequencies provides a general idea of corrosion inhibition performance. The more negative the phase angle, the more capacitive the electrochemical behavior (Fig. $2 b$ and Fig. 2d). Charge-transfer resistance increment raises the current tendency to pass through the capacitor in the circuit. Also, increment of the phase angle at relaxation frequency in presence of inhibitors indicates the increase of capacitive response. Such a phenomenon could be attributed to high corrosion inhibition activity of inhibitor. We noted also that the $\mathrm{C}_{\mathrm{dl}}$ value does not reach a minimum value at $100 \mathrm{ppm}$ of concentration. It is clear, according to the Figure 4, that the adsorption is monolayer for the concentrations 50 and $100 \mathrm{ppm}$. 
On the other hand, the adsorption is multi-layered for the high concentrations of 250 and $500 \mathrm{ppm}$. Since there is a multilayer deposition on the surface, the continuous decreasing of capacitance arrived at minimum values for the 250 and $500 \mathrm{ppm}$ concentrations but the resistance does not increase. This reduction in resistance is due to the local fractures of the multilayers, which generates the pores at the level of these fractures. From where, the electrolyte penetrates into these pores and the resistance makes an ohmic drop.

\section{Scanning electron microscopy}

SEM micrographs obtained from steel surface specimens immersion in $0.1 \mathrm{M} \mathrm{NaOH}+0.5 \mathrm{M}$ $\mathrm{NaCl}$ solution for $6 \mathrm{~h}$ in the absence and presence of $100 \mathrm{ppm}$ of prickly pear methanolic extract are shown in Fig. 5a-d.The Fig. 5a, which is the micrograph of the mild steel polished surface, showed polished mild steel surface; the polishing stretches were also visible on the surface. Fig. $5 b$ revealed the SEM image of the mild steel surface exposed to inhibited $0.1 \mathrm{M} \mathrm{NaOH}+0.5 \mathrm{M} \mathrm{NaCl}$ solution for $6 \mathrm{~h}$ in the presence of $100 \mathrm{ppm}$ of prickly pear methanolic extract at $25^{\circ} \mathrm{C}$. There are less pits and cracks observed in the micrographs. The surface analysis results suggest higher adsorption of inhibitor on the surface, which support the EIS results. The Fig. 5c, introduced in $0.1 \mathrm{M} \mathrm{NaOH}+0.5 \mathrm{M} \mathrm{NaCl}$ solution for $6 \mathrm{~h}$ in the presence of $100 \mathrm{ppm}$ of prickly pear methanolic extract at $45^{\circ} \mathrm{C}$, is rougher with clear pits and cavities. The Fig. $5 \mathrm{~d}$, exposed to $0.1 \mathrm{M} \mathrm{NaOH}+$ $0.5 \mathrm{M} \mathrm{NaCl}$ solution for $6 \mathrm{~h}$ in the presence of $100 \mathrm{ppm}$ of prickly pear methanolic extract at $25^{\circ} \mathrm{C}$, it can be observed that the mild steel surface was more damage. In other words, the mild steel surface was strongly damaged in the higher temperature. However, it was shown that there was much less damage on the surface of the mild steel and good protective film adsorbed on specimens surface which is responsible for the inhibition of corrosion with prickly pear methanolic extract in $0.1 \mathrm{M} \mathrm{NaOH}+0.5 \mathrm{M} \mathrm{NaCl}$ solution.

Table 1

Impedance parameters for carbon steel in $0.1 \mathrm{M} \mathrm{NaOH}$ in the absence and presence of Prickly Pear aqueous extract and in $0.1 \mathrm{M}$ $\mathrm{NaOH}+0.5 \mathrm{M} \mathrm{NaCl}$ in the absence and presence of Prickly Pear methanolic extract at 25

\begin{tabular}{|c|c|c|c|c|c|}
\hline System & $\operatorname{Re}\left(\Omega . \mathrm{cm}^{2}\right)$ & $\mathrm{R}_{\mathrm{ct}}\left(\Omega \cdot \mathrm{cm}^{2}\right)$ & $\mathrm{Rp}\left(\Omega . \mathrm{cm}^{2}\right)$ & $\mathrm{C}_{\mathrm{dl}}\left(\mu \mathrm{F} \mathrm{cm} \mathrm{cm}^{-2}\right)$ & $\eta(\%)$ \\
\hline $0.1 \mathrm{M} \mathrm{NaOH}$ & 4.9 & 8.1 & 13 & 114 & - \\
\hline $50 \mathrm{ppm}$ & 4.5 & 22.3 & 26.8 & 96.7 & 63.6 \\
\hline $100 \mathrm{ppm}$ & 6.1 & 262 & 268.1 & 60.2 & 96.9 \\
\hline $250 \mathrm{ppm}$ & 8.4 & 2.8 & 11.2 & 29.9 & - \\
\hline $500 \mathrm{ppm}$ & 10.6 & 2 & 12.6 & 30.6 & - \\
\hline $0.1 \mathrm{M} \mathrm{NaOH}+0.5 \mathrm{M} \mathrm{NaCl}$ & 1.7 & 7 & 8.7 & 82.5 & - \\
\hline $50 \mathrm{ppm}$ & 1.7 & 9.7 & 11.4 & 71.6 & 28.1 \\
\hline $100 \mathrm{ppm}$ & 1.7 & 59.6 & 61.3 & 70.4 & 88.3 \\
\hline $250 \mathrm{ppm}$ & 2.8 & 7.49 & 10.3 & 64.7 & 7.1 \\
\hline $500 \mathrm{ppm}$ & 4.4 & 23.3 & 27.7 & 61.7 & 70.1 \\
\hline
\end{tabular}
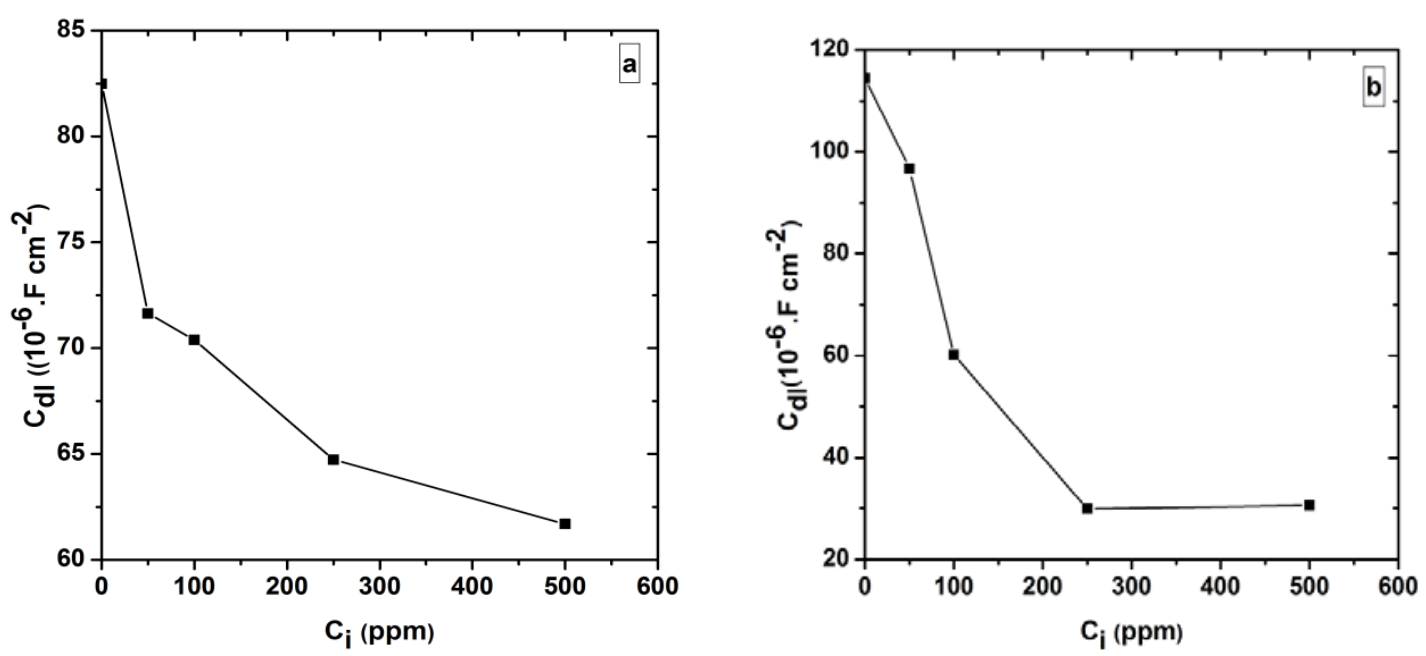

Fig. 4 - Evolution of capacity a) without and with addition of different concentrations of Preackly Pear methanolic extract b) without and with addition of different concentrations of Preackly Pear aqueous extract. 

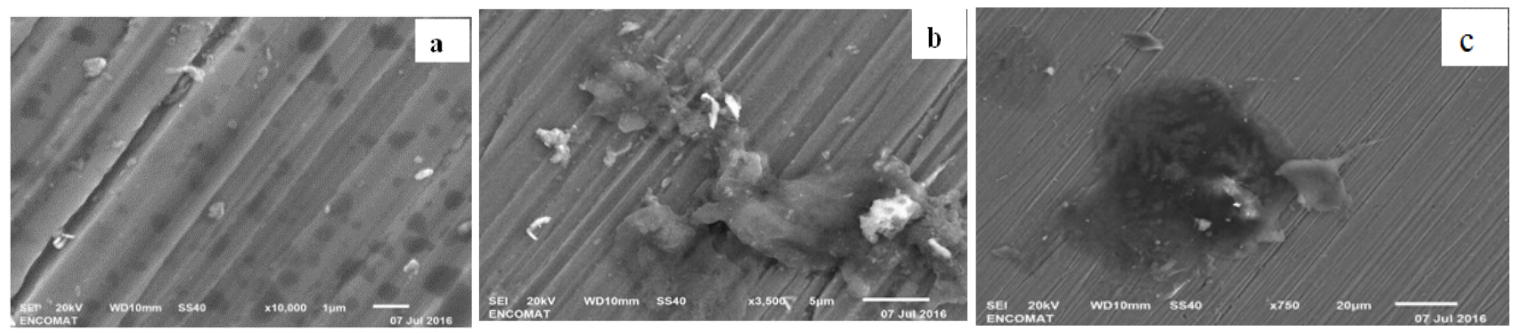

Fig. 5 - SEM micrographs of the mild steel surface: a) polished surface b) after immersion in $0.1 \mathrm{M} \mathrm{NaOH}+0.5 \mathrm{M} \mathrm{NaCl}$ solution for $6 \mathrm{~h}$ in the presence of $100 \mathrm{ppm}$ of prickly pear methanolic extract at $25^{\circ} \mathrm{C}$ c) after immersion in $0.1 \mathrm{M} \mathrm{NaOH}+0.5 \mathrm{M} \mathrm{NaCl} \mathrm{solution}$ for $6 \mathrm{~h}$ in the presence of $100 \mathrm{ppm}$ of prickly pear methanolic extract at $45^{\circ} \mathrm{C}$.
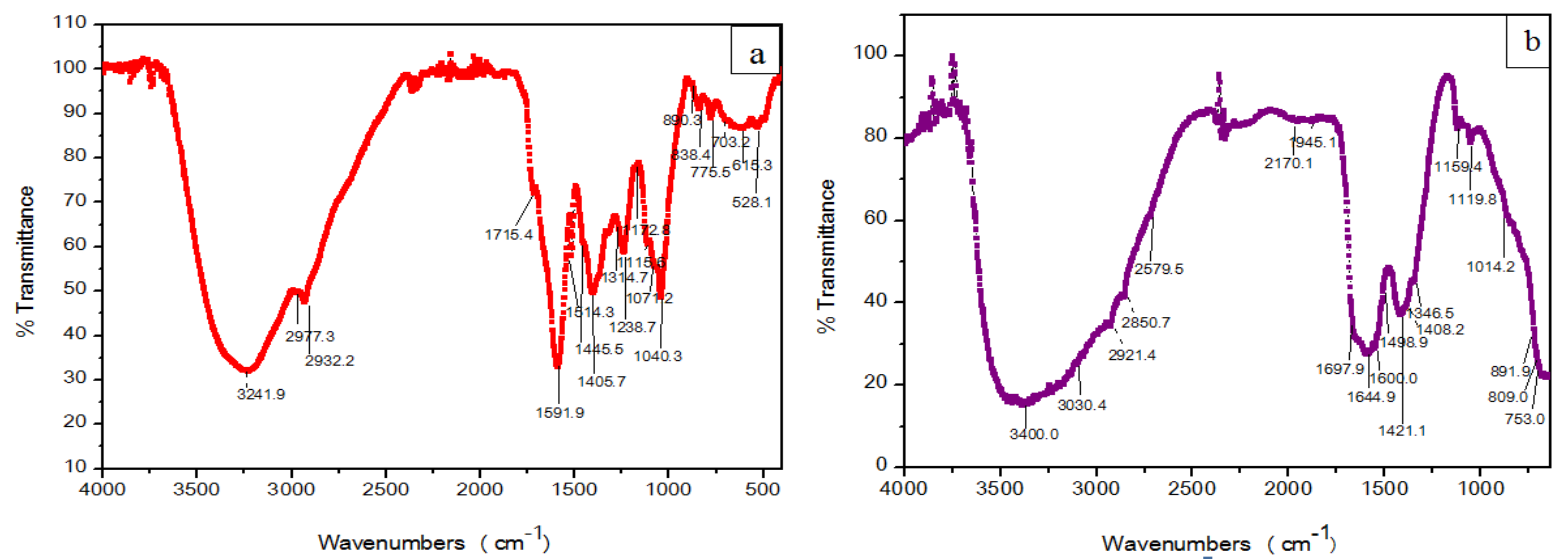

Fig. 6 - FTIR spectra of a) Prickly Pear powder of methanolic extract b) surface film of the C-steel specimen after $6 \mathrm{H}$ immersion in $0.1 \mathrm{M} \mathrm{NaOH}+0.5 \mathrm{M} \mathrm{NaCl}$ containing $100 \mathrm{ppm}$ of Prickly Pear methanolic extract at $25^{\circ} \mathrm{C}$.

\section{FT-IR analysis}

FTIR is a powerful technique that is always used to determine the type of bonding for organic inhibitors absorbed on the metal surface ${ }^{36-38}$. Fig. 6a shows the FTIR spectrum of the Prickly Pear powder of methanolic extract. In this sample appear bands at $2800-3000 \mathrm{~cm}^{-1}$ that indicate the presence of C-H band. The broadband at 3240$3270 \mathrm{~cm}^{-1}$ is attributed to N-H stretching (obligatory) and another around $1600 \mathrm{~cm}^{-1}$ corresponds to $\mathrm{C}=\mathrm{O}$ of $\mathrm{N}-\mathrm{C}=\mathrm{O}$ stretching vibrations, which may indicate the presence of the amide group, but must be confirmed by the presence of $\mathrm{N}$ elementary analyzes. Also, the broadband at $3200 \mathrm{~cm}^{-1}$ may be provided by the vibration mode of the phenolic $\mathrm{OH}$ group, which is also reflected by the bands in the area of $1600 \mathrm{~cm}^{-1}$ by the mode of vibration of the $\mathrm{C}=\mathrm{C}$ of the aromatic cycle, and the bands at 12551240 (a little wide, phenolic binding CO), 1170 (phenolic $\mathrm{OH}$ ) and $835 \mathrm{~cm}^{-1}$ (phenolic $\mathrm{OH}$ ). The bands at $1000-1100 \mathrm{~cm}^{-1}$ may be due to stretching vibration modes of the $\mathrm{C}-\mathrm{O}$ bands in the $\mathrm{C}-\mathrm{OH}$ group. The band of $1715 \mathrm{~cm}^{-1}$ zone is the $\mathrm{C}=\mathrm{O}$ band, probably the carboxylic acid $(\mathrm{COOH})$. Fig. $6 \mathrm{~b}$ illustrates the FTIR spectrum of the surface film on the C-steel specimen after $6 \mathrm{H}$ of immersion in $0.1 \mathrm{M} \mathrm{NaOH}+0.5 \mathrm{M} \mathrm{NaCl}$ containing $100 \mathrm{ppm}$ of Prickly Pear methanolic extract. In the sample, several areas of the surface were measured by the FTIR-microscopy to observe if there is homogeneity according to the possible compound. Using a MCTA detector (mercury cadmium telluride) which is used in measurements of microscopyFTIR, does not work with frequencies lower than $650 \mathrm{~cm}^{-1}$ so that the vibration modes of binding $\mathrm{Fe}-$ $\mathrm{O}$ of $\mathrm{Fe}$ (III) oxides $\left(\mathrm{Fe}_{2} \mathrm{O}_{3}\right)$ cannot be observed, such as hematite $\left(540\right.$ y $\left.470 \mathrm{~cm}^{-1}\right)$ or maghemite

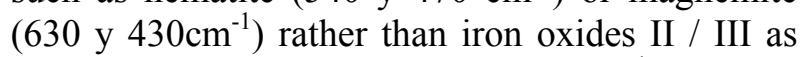
magnetite $\left(\mathrm{Fe}_{3} \mathrm{O}_{4}\right)\left(570\right.$ and $\left.390 \mathrm{~cm}^{-1}\right)$.A large number of wave shows a very broad band between 2500 y $3700 \mathrm{~cm}^{-1}$ which may be provided by a large number of vibration modes of different links between it the $\mathrm{O}-\mathrm{H}$ bond. As shown in the literature that the band has a maximum absorption at $\approx 3400 \mathrm{~cm}^{-1}$ indicating the presence of polyphenols that they have reacted with the metal, in this case steel. In the region of $1500-1700 \mathrm{~cm}^{-1}$ broad band was observed, which may indicate the formation of an amorphous nature of the complex. The band of $1245 \mathrm{~cm}^{-1}$ does not appear in Fig. $6 \mathrm{~b}$ but $1407 \mathrm{~cm}^{-1}$, generally moves at higher wave 
number (1408-1423 $\left.\mathrm{cm}^{-1}\right)$. Several bands are detected which may be due to the presence of various iron oxides groups. The bands around 1018 and $750 \mathrm{~cm}^{-1}$ could be due to lepidocrocite bending modes $\mathrm{FeO}(\mathrm{OH})$. The band of 1344-1350 $\mathrm{cm}^{-1}$ may be due to the bending mode of the $\mathrm{OH}$ group of a ferric hydroxide $\mathrm{Fe}(\mathrm{OH})_{3}$. The vibration band of this link would be around $3030 \mathrm{~cm}^{-1}$, and the bands of $1638-1645 \mathrm{~cm}^{-1}, 890 \mathrm{~cm}^{-1}$ and $\approx 800 \mathrm{~cm}^{-1}$ could be due to different modes of bending goethite $\mathrm{FeO}(\mathrm{OH})$.

\section{EXPERIMENTAL}

\section{Materials and methods}

\section{The fruit}

Prickly Pear grows, essentially, in the tropical and subtropical regions. It is one of the fewest plants able to adapt to difficult ambient conditions. ${ }^{17}$ Prickly Pear grows all throughout Tunisia, in areas characterized by water stress and low soil quality. Fresh Prickly Pearfruits have been used as human food while cladodes have been exploited as livestock forage,essentially during the dry season. In Tunisia, this cactus has beenused to prevent soil degradation and to control desertification. ${ }^{18}$.The chemical composition of the cactus forage varies with the cultivar, the development stage, the fertilization, the plant population and thecladode order. ${ }^{19}$ Nevertheless, the main shared compounds are pectin, mucilage and minerals. ${ }^{20}$

\section{Extraction procedure}

The fruits of the Prickly Pear were harvested during the month of April in the Tunis region. After thoroughly washing to remove adherences, the fruits were cut into small pieces. After that, they were dry ground with a household blender. The resulting sauce was weighed $(750 \mathrm{~g})$ and was stored in the refrigerator at temperature of $10^{\circ} \mathrm{C}$ until use.

To exploit the polar fraction of the Prickly Pear as an inhibitor of corrosion, we conducted two types of extract:

a) Aqueous extract.We made macerating $372 \mathrm{~g}$ sauce in $0.5 \mathrm{~L}$ of water for 16 hours and then made the maceration stirring for 6 hours. The aqueous extract was sieve filtered using successively small pore diameters: $1 \mathrm{~mm}$ and $0.080 \mathrm{~mm}$. Filtration was carried out for 24hours for recovering $450 \mathrm{~mL}$ of filtrate having $11.4 \mathrm{~g} / \mathrm{L}$ concentration.

b) Methanolic extract.The same procedure as for the aqueous extract was followed. The concentration of the methanolic extract was $14.6 \mathrm{~g} / \mathrm{L}$.

\section{Preparation of the specimens}

Mild steel $(0.023 \% \mathrm{P} ; 0.04 \% \mathrm{Si} ; 0.017 \% \mathrm{Mn} ; 0.078 \% \mathrm{C}$; $0.02 \% \mathrm{~S} ; 0.002 \% \mathrm{Mo}$; Fe balance) specimens of $0.1 \mathrm{~cm}^{2}$ exposed surface were used for the electrochemical studies. The specimens were polished successively using 400 and 1200 emery papers and washed with distilled water before electrochemical testing.

\section{Electrolyte}

The solutions employed were prepared using analytical grade chemicals and deionized water $(\rho=18 \mathrm{M} \Omega \mathrm{cm})$. Three solutions were prepared, a reference $0.1 \mathrm{M} \mathrm{NaOH}$ solution and two more solutions with $\mathrm{NaCl}$ added to the blank solution to reach $0.1 \mathrm{M}$ and $0.5 \mathrm{M} \mathrm{NaCl}$.

The concentration range of inhibitor (plant extract) employed was varied from 50 to $500 \mathrm{ppm}$ and the electrolyte used was $100 \mathrm{~mL}$.

\section{Electrochemical measurements \\ Open circuit potential measurements}

A three-electrode cell assembly consisting of a mild steel coupon of $0.1 \mathrm{~cm}^{2}$ nominal active surface embedded in a specimen holder was the working electrode (WE) and the only exposed area to the corrosive media the electrode was abraded with emery paper (grade 500-600-1200) on the test face, rinsed with distilled water and dried. A large area graphite sheet was the counter electrode (CE), and a saturated calomel electrode the reference electrode (RE).Before starting the experiments, the working electrode was immersed in test solution for $1 \mathrm{~min}$ atopen circuit potential (OCP). The electrochemical cell contained $100 \mathrm{ml}$ of electrolyte measurements were performed at $25,30,35,40$ and $45^{\circ} \mathrm{C}$.

\section{Electrochemical impedance spectroscopy (EIS)}

An Autolab ${ }^{\circledR}$ potentiostat PGSTAT 20 equipped with FRA32modulewas employed for the electrochemical measurements. The data analysis was conducted using the dedicated Autolab ${ }^{\circledR}$ software that implements the fitting impedance utility developed by B. A. Boukamp. ${ }^{21}$ The impedance measurements were carried out at the open circuit potential $\left(\mathrm{E}_{\mathrm{OCP}}\right)$ and FRA software. The alternating current frequency range was extended from $10 \mathrm{kHz}$ to $0.01 \mathrm{~Hz}$ with a signal amplitude perturbation of $0.01 \mathrm{mV}$ rms.

\section{SEM analysis}

Specific test couponswere exposed for 6 hours at $25{ }^{\circ} \mathrm{C}$ and at $45^{\circ} \mathrm{C}$ in $100 \mathrm{ml}$ of $0.1 \mathrm{M} \mathrm{NaOH}+0.5 \mathrm{M} \mathrm{NaCl}$ having $100 \mathrm{ppm}$ inhibitor, the optimal concentration of the inhibitor. After washing and drying, the specimens were examined for their structural and topographical features using a JEOL JSM65105Scanning electron microscope (SEM).

\section{FT-IR characterization}

The pure aqueous and methanolic extracts and the scratched corrosion products formed on the mild steel surface were analyzed separately with the help of FT-IR (NICOLETFT-IR spectrometer Model no:6700) spectra using the $\mathrm{KBr}$ pellet method.

\section{CONCLUSIONS}

In this paper, we demonstrated that aqueous extract of Prickly Pear gives an inhibition efficiency around $96.9 \%$ in $\mathrm{NaOH}(0.1 \mathrm{M})$ solution while the inhibition efficiency of methanol extract exceeded $88.3 \%$ in $0.1 \mathrm{M} \mathrm{NaOH}+0.5 \mathrm{M} \mathrm{NaCl}$ solution, presenting a good inhibitor for steel corrosion. The impedance data was obtained via adsorption of the extract species on the C-steel surface. The inhibiting protection increases proportionally with the inhibitor concentration reached a maximum at $100 \mathrm{ppm}$. SEM reveals the 
formation of a smooth surface on C-steel in the presence of prickly pear extract compounds probably due to the formation of an adsorptive film of electrostatic character. Besides, FTIR results indicate the presence of a uniform and dense adsorptive film over the C-steel surface, which efficiently inhibits the corrosion of c-steel. Those results were confirmed by the impedance study, which presented two phenomena included a charge-transfer and a passive layer.

\section{REFERENCES}

1. A. K. Singh, S. Mohapatra and B. Pani, J. Ind. Eng. Chem., 2016, 33, 288-297; doi:10.1016/j.jiec.2015. 10.014 .

2. G. L. F. Mendonça, S. N. Costa, V. N. Freire, P. N. S. Casciano, A. N. Correia and P. de Lima-Neto, Corros Sci., 2017, 115, 41-55; doi:10.1016/j.corsci.2016.11.012.

3. M. Prabakaran, S.-H. Kim, V. Hemapriya and I.-M. Chung, J. Ind. Eng. Chem., 2016, 37, 47-56; doi:10.1016/j.jiec.2016.03.006.

4. S. Mo, H.-Q. Luo and N.-B. Li, Chem Pap., 2016, 70,1131-1143; doi:10.1515/chempap-2016-0055.

5. B. Guitián, X. R. Nóvoa and B. Puga, Electrochim Acta., 2011, 56, 7772-7779; doi:10.1016/j.electacta.2011. 03.055 .

6. K. Cellat, F. Tezcan, B. Beyhan, G. Kardaş and H. Paksoy, Constr. Build. Mater., 2017, 143, 490-500; doi:10.1016/j.conbuildmat.2017.03.165.

7. H. Nahali, H. Ben Mansour, L. Dhouibi and H. Idrissi, Constr. Build Mater., 2017, 141, 589-597; doi:10.1016/ j.conbuildmat.2017.02.147.

8. H. Verbruggen, H. Terryn and I. De Graeve, Constr. Build. Mater., 2016, 124, 887-896; doi:10.1016/ j.conbuildmat.2016.07.115.

9. P. B. Raja and M. G. Sethuraman, Mater. Lett., 2008, 62, 113-116; doi:10.1016/j.matlet.2007.04.079.

10. G. Pena, C, M. Abreu and M. J. Crist, J. Electroanal. Chem., 2004, 572, 335-345; doi:10.1016/j.jelechem. 2004.01.015.

11. A.Y. El-Etre, M. Abdallah and Z. E. El-Tantawy, Corrosion Sci., 2005, 47, 385-395; doi:10.1016/j.corsci. 2004.06.006.

12. N. Etteyeb, L. Dhouibi, H. Takenouti, M. C. Alonso and E. Triki, Electrochim. Acta, 2007, 52, 7506-7512; doi:10.1016/j.electacta.2007.03.003.

13. V. K. Gouda, Br. Corros. J., 1970, 5; doi.org/10.1179/ 000705970798324450.

14. L. Valek, S. Martinez, D. Mikulic and I. Brnardic, Corrosion Sci., 2008, 50, 2705-2709; doi:10.1016/j. corsci.2008.06.018.

15. J. Hugo Cota-Sánchez, Chapter 28: "Nutritional Composition of the Prickly Pear (Opuntia ficus-indica)
Fruit", in "Nutritional Composition of Fruit Cultivars", 2015, p. 691-709; doi:10.1016/B978-0-12-4081178.00028-3.

16. O. Khatabi, H. Hanine, D. Elothmani and A. Hasib, Arab. J. Chem., 2016, 9, 278-281; doi:10.1016/j.arabjc.2011. 04.001 .

17. H. Ha and P. Felker, J. Arid. Environ., 1997, 36, 133148; doi:10.1006/jare.1996.0202.

18. H. N. le Houérou, Options Méditerranéennes, Ser B., 2002, 37, 21-29.

19. J. C. Dubeux and U. Brazil, Use of Cactus for Livestock.

20. F. C. Stintzing and R. Carle, Mol. Nutr. Food. Res., 2005, 49, 175-194; doi:10.1002/mnfr.200400071.

21. B. A. Boukamp, Solid State Ionics, 1986, 18-19, 136-140. doi:10.1016/0167-2738(86)90100-1.

22. S. Joiret, M. Keddam, X. R. Nóvoa, M. C. Pérez, C. Rangel and H. Takenouti, Cem. Concr. Compos., 2002, 24,7-15. doi:10.1016/S0958-9465(01)00022-1.

23. M.Sánchez-Moreno, H. Takenouti, J. J. García-Jareño, F. Vicente and C. A. Alonso, Electrochim. Acta, 2009, 54, 7222-7226; doi:10.1016/j.electacta.2009.07.013.

24. C. M. Abreu, M. J. Cristóbal, R. Losada, X. R. Nóvoa, G. Pena and M. C. Pérez, Electrochim. Acta, 2006, 51, 1881-1890; doi:10.1016/j.electacta.2005.06.040.

25. M.Lebrini, G. Fontain, L. Gengembre, M. Traisnel, O. Lerasleand N. Genet, Appl. Surf. Sci., 2008, 254, 6943-6947; doi:10.1016/j.apsusc.2008.04.112.

26. K. F. Khaled, J. Electrochem. Soc., 2010, 157,116; doi:10.1149/1.3274915.

27. L. J. Li, X. P. Zhang, J. L. Lei, J. X. He and S. T. Zhang, Asian J. Chem., 2012, 24, 1649-1653.

28. F. Mansfeld, M. W. Kendigand S. Tsai, Corrosion, 1982, 38, 478-485; doi:10.5006/1.3577363.

29. H. Shih and F. A. Mansfeld, Corros. Sci., 1989, 29, 12351240; doi:10.1016/0010-938X(89)90070-X.

30. S. Martinez, M. Metikoš-Huković, J. Appl. Electrochem., 2003, 33, 1137-1142.

31. F. Bentiss, M. Lebrini, H. Vezin, F. Chai, M. Traisnel and M. Lagrené, Corros. Sci., 2009, 51, 2165-2173; doi:10.1016/j.corsci.2009.05.049.

32. M. Behpour, S. M. Ghoreishi, N. Soltani, M. SalavatiNiasari, M. Hamadanian and A. Gandomi, Corros. Sci., 2008, 50, 2172-2181; doi:10.1016/j.corsci.2008.06.020.

33. M. Lagren, Corros. Sci., 2002, 44, 573-588; doi:10.1016/ S0010-938X(01)00075-0.

34. M. I. Awad, J. Appl. Electrochem., 2006, 36, 1163-1168; doi:10.1007/s10800-006-9204-1.

35. E. E. Oguzie, Y. Li and F. H. Wang, Electrochim. Acta., 2007, 53, 909-914; doi:10.1016/j.electacta.2007.07.076.

36. X.-H. Li, S.-D. Deng, H. Fu and G.-H. Mu, J. Appl. Electrochem., 2009, 39, 1125-1135; doi:10.1007/s10800008-9770-5.

37. S. Deng, X. Li and H. Fu, Corros. Sci., 2011, 53, 760768; doi:10.1016/j.corsci.2010.11.002.

38. Q. Qu, S. Jiang, L. Li, W. Bai and J. Zhou, Corros. Sci., 2008, 50, 35-40; doi:10.1016/j.corsci.2007.06.008. 